University of Nebraska - Lincoln

DigitalCommons@University of Nebraska - Lincoln

\title{
WIRELESS SENSOR NETWORK EFFECTIVELY CONTROLS CENTER PIVOT IRRIGATION OF SORGHUM
}

\author{
Susan A. O'Shaughnessy \\ USDA-ARS, Susan.OShaughnessy@ars.usda.gov \\ Steven R. Evett \\ USDA-ARS, steve.evett@ars.usda.gov \\ Paul D. Colaizzi \\ USDA-ARS, Paul.Colaizzi@ARS.USDA.GOV \\ Terry A. Howell \\ USDA-ARS, Terry.Howell@ars.usda.gov
}

Follow this and additional works at: https://digitalcommons.unl.edu/usdaarsfacpub

O'Shaughnessy, Susan A.; Evett, Steven R.; Colaizzi, Paul D.; and Howell, Terry A., "WIRELESS SENSOR NETWORK EFFECTIVELY CONTROLS CENTER PIVOT IRRIGATION OF SORGHUM" (2013). Publications from USDA-ARS / UNL Faculty. 1852.

https://digitalcommons.unl.edu/usdaarsfacpub/1852

This Article is brought to you for free and open access by the U.S. Department of Agriculture: Agricultural Research Service, Lincoln, Nebraska at DigitalCommons@University of Nebraska - Lincoln. It has been accepted for inclusion in Publications from USDA-ARS / UNL Faculty by an authorized administrator of DigitalCommons@University of Nebraska - Lincoln. 


\title{
WiRELESS SENSOR NeTWORK EFFECTIVELY CONTROLS CENTER PIVOT IRRIGATION OF SORGHUM
}

\author{
S. A. O’Shaughnessy, S. R. Evett, P. D. Colaizzi, T. A. Howell
}

\begin{abstract}
Automatic irrigation scheduling has been demonstrated using wired sensors and sensor network systems with subsurface drip and moving irrigation systems. However, there are limited studies that report on crop yield and water use efficiency resulting from the use of wireless networks to automatically schedule and control irrigations. In this 2011 study, a multinode wireless sensor network (WSN) system was mounted onto a six-span center pivot equipped with a commercial variable rate irrigation (VRI) system. Data from the WSN was used to calculate an integrated crop water stress index (iCWSI) threshold for automatic irrigation scheduling of grain sorghum. Crop response to the automatic method was compared with manual irrigation scheduling using weekly direct soil water measurements. The WSN system was operational throughout $98 \%$ of the growing season, and the delivery rates for data packets from the different nodes ranged between $90 \%$ and $98 \%$. Dry grain yields and WUE in the automatic and manual treatment plots were not significantly different from each other at any of the irrigation levels. Crop water use and WUE were highest in the I $_{80}$ irrigation treatment level. Average seasonal integrated crop water stress indices were negatively correlated to irrigation treatment amounts in both the manual and automatic plots and correlated well to crop water use. These results demonstrate that it is feasible to use WSN systems for irrigation management on a field-scale level.
\end{abstract}

Keywords. Irrigation scheduling, Crop water stress index, Center pivot, sorghum, Variable rate irrigation, Wireless.

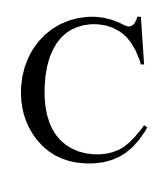
ontinuous spatiotemporal crop monitoring is fundamental to site-specific irrigation and automated control of crop water productivity (Evett et al., 2002). Automatic irrigation scheduling has been demonstrated using wired sensor network systems (Peters and Evett, 2008; O'Shaughnessy and Evett, 2010a; O'Shaughnessy et al., 2012a). However, the hard-wired sensor network systems were logistically cumbersome to install and maintain, and not economical for large-scale deployment onto a moving sprinkler irrigation system or drip irrigated field. These limitations were motivation to transition to a wireless sensor network system, which also offered the potential for greater installation flexibility, and allowed for direct integration with the control panel of the center pivot system.

Key factors for successful integration of wireless sensor network systems into commercial moving irrigation or

Submitted for review in September 2012 as manuscript number SW 9921; approved for publication by the Soil \& Water Division of ASABE in July 2013. Presented at the 2012 ASABE Annual Meeting as Paper No. 12-1338246.

The use of trade, firm, or corporation names in this article is for the information and convenience of the reader. Such use does not constitute an official endorsement or approval by the United States Department of Agriculture or the Agricultural Research Service of any product or service to the exclusion of others that may be suitable. USDA is an equal opportunity provider and employer.

The authors are Susan A. O'Shaughnessy, ASABE Member, Research Agricultural Engineer, Steven R. Evett, ASABE Member, Research Soil Scientist, Paul D. Colaizzi, ASABE Member, Research Agricultural Engineer, and Terry A. Howell, ASABE Fellow, Retired, USDA-ARS, Bushland, Texas. Corresponding author: Susan Ann O'Shaughnessy, P.O. Drawer 10, Bushland, TX, 79012; phone: 806-3565770; e-mail: susan.oshaughnessy@ars.usda.gov. large-scale drip irrigation systems include scalability and reliability. Scalability, or the ability of a sensor network system to handle a large number of nodes, is critical for intensive data acquisition or achieving site-specific irrigation at the field scale level (Camilli et al., 2007). Sensor systems can be comprised of a number of different sensing devices; scalability is important for achieving multi-data collection (Lee et al., 2010). For example, Coates and Delwiche (2009) deployed wireless soil moisture, pressure, and temperature sensors to manage multiple sprinklers or drip emitters for automating irrigation management. Kim et al. (2009) implemented closed-loop automated irrigation scheduling using distributed wireless sensor networks comprised of soil water and temperature sensors. Meteorological sensors are often hard-wired to data-logging stations, whereas the agro-meteorological data are often transferred wirelessly to a central location. Wireless capabilities afford the remote monitoring of microclimates and potential widespread access by a number of users. Matese et al. (2009) deployed an advanced vineyard network system comprised of a base agrometeorological station for regional monitoring and a series of wireless peripheral nodes containing meteorological sensors for site-specific microclimate monitoring. The end use of the data was for irrigation scheduling or prevention of crop damage due to frost. Wireless communication using distributed network systems (wireless communication with datalogging instruments) often simplifies the operation of wireless networks by reducing the number of individual wireless end nodes. The power of a large-scale wireless sensor network system (distributed or otherwise) is that it can provide a range of information over a large area. This scenario is applicable to a 
center pivot field, whereby a multi-nodal WSN mounted on a moving irrigation sprinkler can provide real-time spatiotemporal monitoring of crop status for automated irrigation scheduling and control at a field-scale level.

The second key factor to WSN performance is reliability. Accurate data and their dependable throughput and capture throughout a growing season are essential for the implementation of automatic irrigation scheduling and sitespecific irrigation management on a commercial level. There are a number of parameters to consider when addressing wireless data reliability. These include employing architectures with mesh-networking capabilities, low power consumption, and optimizing node siting to eliminate signal attenuation caused by range limitations or blockage by objects in the line of sight of two transceivers; multipath fading; and interference caused by the simultaneous arrival of signals at the receiver (Moring, 2006). Similar to other types of WSNs, a wireless sensor network system mounted on a center pivot can be optimized by ensuring adequate power link margin between nodes. A link margin is a power ratio $(\mathrm{dBm})$ in decibels $(\mathrm{dB})$ of the measured power referenced to one milliwatt (mW). Although RF transmission can be severely attenuated by reflection off the pivot framework or blocked when a tall pivot tire is within the line-of-sight of two nodes, there are methods to improve the network link margin. These include enhancing network topology (point-to-point vs. point-to-multipoint), using multi-cast (rather than unicast) communication, adding routers above the pivot lateral to extend the transmission range, increasing modem antenna height above the pivot swivel, and upgrading antenna gain to increase power transmission. Finally, the ability to remotely monitor sensor battery level, and perform quality assessment on the captured data are of utmost importance to sustaining network reliability, and should be typical maintenance practices for a WSN system. This type of upkeep can be accomplished by providing a graphical user interface to display data (Kim and Evans, 2009) that is posted to a website or stored on the base station computer.

In addition to the use of sensors to remotely monitor crop canopy temperature for detection of crop water stress, spectral radiometers have been used to aid in the detection of disease (West et al., 2003) and insect infestation (Mirik et al., 2007; Yang et al., 2009) within cropped fields. In this use, vegetative indices are calculated based on ratios of reflectance in different visible and near-infrared spectral bands using hand-held, aerial or satellite instrumentation. Vegetative indices have also been used to estimate plant vigor (DeTar and Penner, 2007), crop water use efficiency (Gonzalez-Dugo and Mateos, 2008) and schedule irrigations (Hunsaker et al., 2005).

Our immediate interest in multiband radiometers (MBRs) was to investigate continuous remote spectral reflectance measurements relative to destructive leaf area index (LAI) samples to estimate percent canopy cover. Estimations of canopy cover early in the growing season when canopy cover is less than full can help reduce false positive irrigation signals from thermal radiometric measurements.
Commercialization of sensor-based site-specific irrigation systems will require enhanced network scalability and data transmission reliability, accurate remote measurements, and a functional WSN system. Our goal was to evaluate the performance of a WSN system integrated onto a center pivot sprinkler throughout a typical growing season in the Texas High Plains region. Specific objectives were to assess: (1) the packet delivery rate of the sensor nodes; (2) the relationship between different irrigation amounts and average seasonal integrated CWSI values; and (3) grain yield and crop water use efficiency differences between manual and automatic irrigation scheduling methods using a plant feedback algorithm.

\section{Methods ANd Materials \\ IRRIGATION SYSTEM}

A six-span center pivot located at the USDA-ARS CPRL at Bushland, Texas $\left(35^{\circ} 11^{\prime} \mathrm{N}, 102^{\circ} 06^{\prime} \mathrm{W}, 1174 \mathrm{~m}\right.$ above mean sea level) with a Pro-panel 2 was retrofitted with a commercial variable rate irrigation (VRI) system (Valmont Industries Inc., Valley, Nebr.). The field soil was a Pullman clay loam, a fine, mixed, superactive, thermic, Torrertic Paleustoll (Soil Survey Staff, 2004). The field capacity $\left(0.31 \mathrm{~m}^{3} \mathrm{~m}^{-3}\right)$ and wilting point $\left(0.19 \mathrm{~m}^{3} \mathrm{~m}^{-3}\right)$ water contents were assumed uniform across the center pivot field.

The VRI system (O'Shaughnessy et al., 2011a) delivered variable irrigation amounts radially along the pivot by regulating the duty cycle ("on" time vs. "off" time) of hydraulic valves controlling flow to 24 sets of sprinkler banks (six contiguous drop hoses). Flexible polyethylene drop hoses were spaced $1.5 \mathrm{~m}$ apart and were $19 \mathrm{~mm}(3 / 4 \mathrm{in}$.) in diameter, and equipped with a pressure regulator rated at $41 \mathrm{kPa}$ (6 psi). Irrigations were delivered using low energy precision application (LEPA) drag socks (Lyle and Bordovsky, 1983) in every other furrow. The commercial VRI system came equipped with a GPS, but we used our own wireless GPS node at the end tower of the pivot during this study.

Irrigation treatment amounts were held constant for each sprinkler bank, i.e. the same irrigation rate was applied circumferentially across automatic and manual sectors on one-half of the center pivot throughout the growing season (fig. 1). The other half lay fallow to even out the soil water profile for the next irrigation season.

These irrigation rates were established by building and uploading a prescription map to the pivot control panel at the beginning of the growing season using commercial VRI software (Rx Loader, version 2.0).

The system was always operated counterclockwise so that the pivot mounted IRTs always viewed unirrigated crop. The system was moved 'dry' around the northeast fallow area before another irrigation sequence. The fallow area was intended for the following growing season to allow removal of residual treatment effects. The maximum system ground speed was $5.9 \mathrm{~m} \mathrm{~min}^{-1}$, and the irrigation capacity was $12.7 \mathrm{~L} \mathrm{~d}^{-1} \mathrm{~m}^{-2}\left(9.5 \mathrm{gpm} \mathrm{acre}^{-1}\right)$. 
Mast

Wireless infrared thermometer

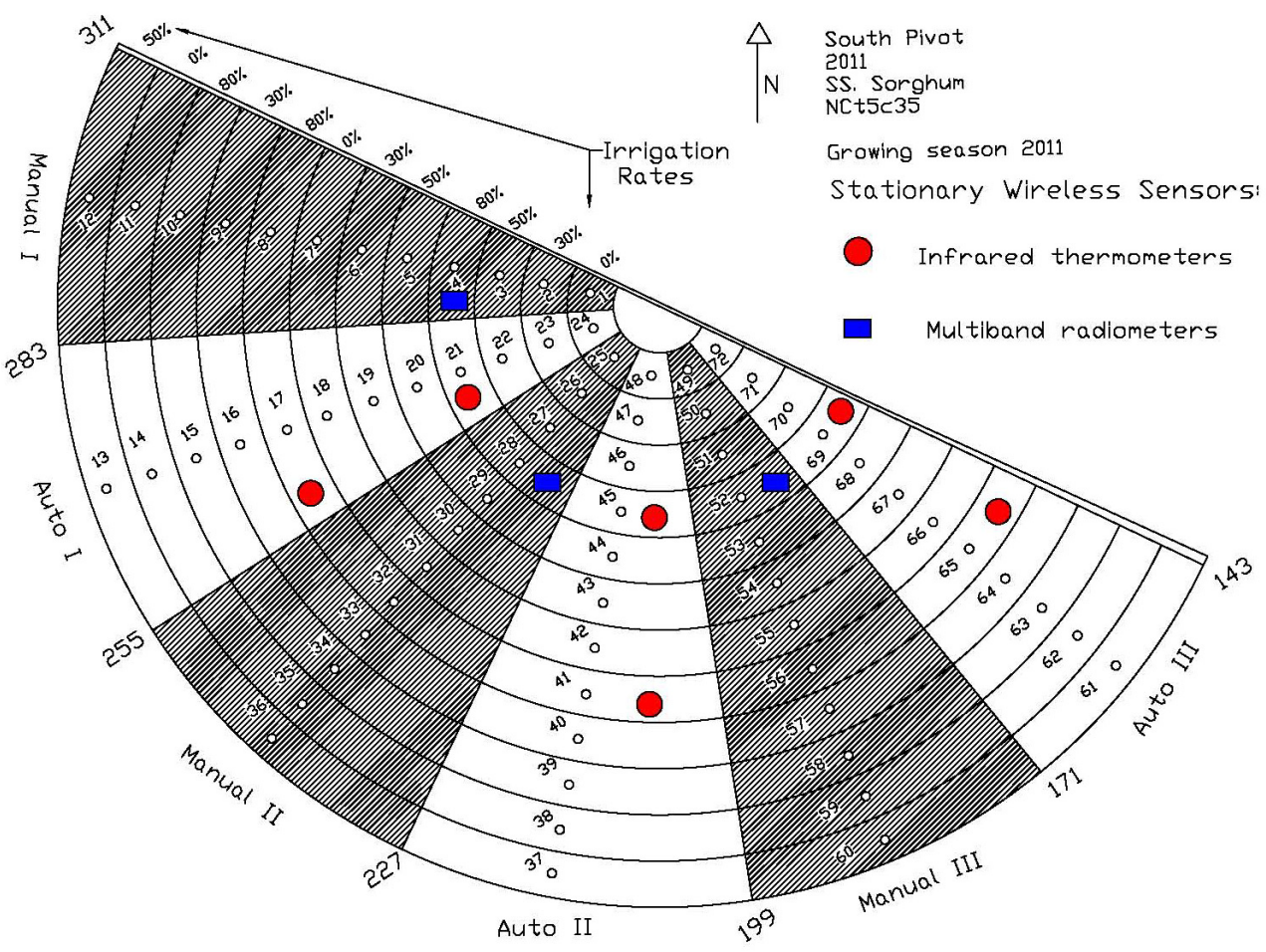

Figure 1. Experimental layout under the 6-span center pivot system shown for the 2011 growing season. Irrigation methods, manual based on soil water content measurements (shaded sectors) and automatic (non-shaded sectors), were alternated over half of the field and replicated three times. Each pie-shaped sector contained irrigation treatments of $\mathbf{8 0} \%, \mathbf{5 0} \%, \mathbf{3 0} \%$, and $0 \%$ of replenishment of soil water depletion to field capacity. Inserted photograph showing wireless infrared thermometers mounted on masts forward of the pivot lateral. One IRT is located at the edge of each concentric irrigation treatment border.

\section{Wireless Sensor Nodes}

In general, wireless sensor node architecture included the original equipment manufacturer (OEM) sensor, radio frequency (RF) module for communication, ARS-designed electronic interface circuit board with microprocessor, battery pack module with recharge circuit, and a solar panel for battery charging (fig. 2).

The wireless IRT nodes were comprised of the OEM IRT detector or infrared thermometer with a narrow field-of-view (model MLX90614-BCF, half view angle of $10^{\circ}$, Melexis, Leper, Belgium) interfaced with an XBee RF module (Digi International, Minnetonka, Minn.) using an ATMEGA88PU microcontroller (ATMEL, Raleigh, N.C.). The detector temperature was self-compensating using proprietary chip architecture and software, which enabled the electronic circuit interface board for ADC (analog to digital conversion) and
UART (universal asynchronous receiver transmitter) communication to be streamlined. The IRT nodes were calibrated in a controlled temperature chamber (Environmental Growth Chambers, Inc., Chagrin Falls, Ohio) against a blackbody calibrator (CES100, Electro Optical Industries, Inc., Santa Barbara, Calif.) using methods described by O'Shaughnessy et al. (2011b). The battery pack (4-AA NiMH) was housed separately from the detector and electronic interface board in a weather-proof module.

The wireless GPS node located at the end-tower was a surface mount GPS IC chip (Tyco Electronics, A1029-A GPS receiver module, WAAS enabled global positioning system, Munich, Germany) interfaced with a XBee module. A $8 \mathrm{dBi}$ patch antenna was connected to the XBee module and the entire sensor module was powered with a $6 \mathrm{~V}, 7 \mathrm{AH}$ sealed lead acid battery. 


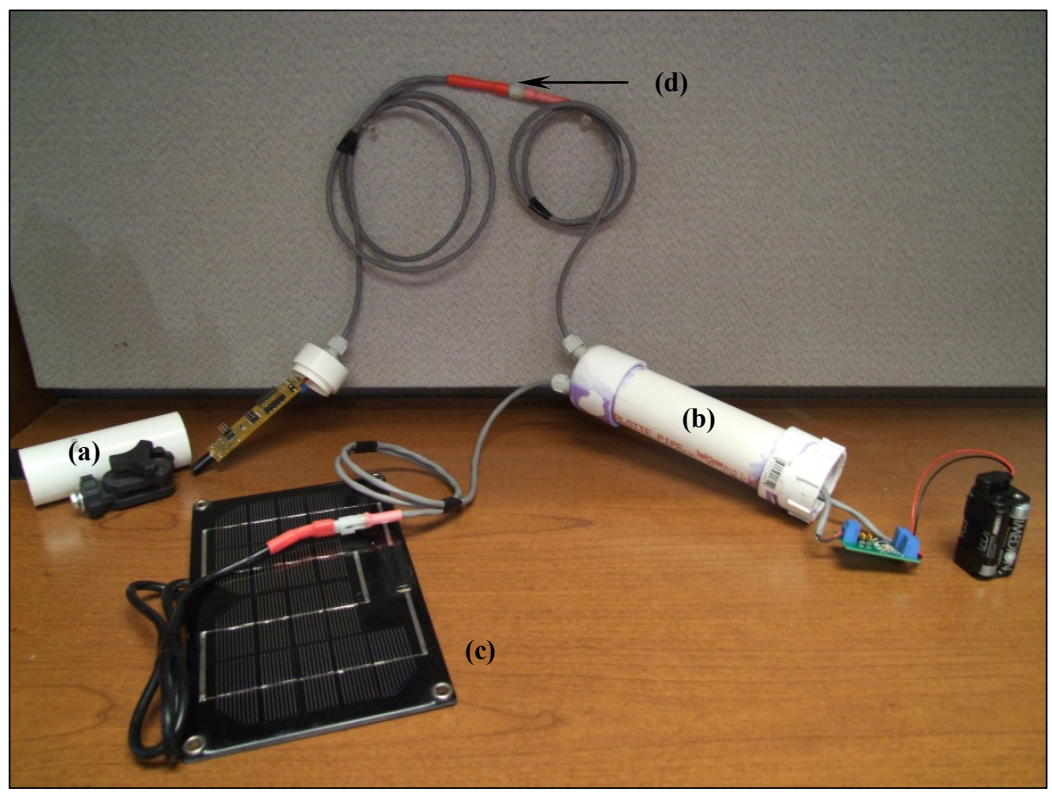

Figure 2. Example of sensor module for a wireless IRT sensor: (a) sensor housing; (b) battery housing, recharge circuit, and battery pack; (c) solar panel; and (d) molex connectors for power supply cords.

The MBR sensor nodes (field of view of $20^{\circ}$ ) were similar in architecture to the IRT (i.e., they were comprised of a sensor, battery, and solar panel module). The OEM detectors for the MBR sensor nodes were four photodiode filter/detectors (Intor, Inc., Socorro, N. Mex.) with bands in the NIR $(880 \mathrm{~nm} \pm 10)$, red $(685 \mathrm{~nm} \pm 10)$, green $(560 \mathrm{~nm}$ $\pm 10)$, and blue $(450 \mathrm{~nm} \pm 20)$ wavelengths $(\lambda)$. Ten data samples were taken with each photodiode filter every 5 min, averaged, stored, and transmitted autonomously from each of these wireless nodes to the base station (table 1). The battery pack (6 V, 4.4 AH sealed lead acid) was housed separately from the detector and electronic interface board in a weather-proof module.

The IRT and MBR nodes were designed with logic control of the pin sleep line to the RF module, which reduced power consumption when not transmitting. Peak current draw for a data transmission event was $35 \mathrm{~mA}$ for all sensor nodes. Current consumption at sampling for the sensor nodes was highest for the MBR and GPS (Table 1) nodes. Power consumption was improved by eliminating power to the OEM detectors during periods of non-sampling using a programmable voltage regulator or NPN-transistor to control a dual channel MOSFET as a switch.

For the IRT, MBR, and GPS sensors, all data were formatted in hexadecimal code at the sensor level using application-programming interface (API) formatting specific to $\mathrm{XBee}$ modules. The RF modules for all routers and the coordinator were constantly powered to facilitate end-device association.

IRT sensor nodes were mounted on masts at the edge of each concentric treatment area (fig. 1), forward of the LEPA drag socks. The sensors faced inwards towards the canopy in each concentric area at an oblique, down-looking angle and from opposite sides of the concentric area to reduce sun angle effects. Sensors on the pivot lateral and in the field were maintained at a height of $1.5 \mathrm{~m}$ above the

Table 1. Summary of sampling characteristic for sensor nodes.

\begin{tabular}{|c|c|c|c|c|c|}
\hline Sensor System & $\begin{array}{l}\text { Sampling } \\
\text { Frequency }\end{array}$ & Measurements & $\begin{array}{c}\text { Transmission Frequency/ } \\
\text { Packet Size; Number of } \\
\text { Packets Transmitted }\end{array}$ & $\begin{array}{c}\text { Current Draw } \\
\text { during Sampling }\end{array}$ & Utility \\
\hline \multirow[t]{2}{*}{$\begin{array}{l}\text { Infrared } \\
\text { thermometers }\end{array}$} & $12 \mathrm{~s}$ & $\begin{array}{l}\text { Temperature: target, } \\
\text { sensor body }\end{array}$ & $5 \mathrm{~min}$ & $10 \mathrm{~mA}$ & $\begin{array}{l}\text { Monitor crop water } \\
\text { status; }\end{array}$ \\
\hline & $1 \mathrm{~min}$ & Battery voltage & 22 bytes; 5 packets & & Monitor battery charge \\
\hline GPS receiver & $10 \mathrm{~s}$ & Time, position & $\begin{array}{l}1 \text { min } \\
19 \text { bytes; } 1 \text { packet }\end{array}$ & $50 \mathrm{~mA}$ & $\begin{array}{l}\text { Spatiotemporal data } \\
\text { stamping }\end{array}$ \\
\hline $\begin{array}{l}\text { Multiband } \\
\text { radiometers }\end{array}$ & $\begin{array}{l}10 \text { times per } \\
5 \text { min interval }\end{array}$ & $\begin{array}{l}\text { Reflectance: } \\
\text { NIR, red, blue, green }\end{array}$ & $\begin{array}{l}5 \text { min } \\
15 \text { bytes; } 1 \text { packet }\end{array}$ & $60 \mathrm{~mA}$ & $\begin{array}{l}\text { Ground cover, crop } \\
\text { health, biotic stressors }\end{array}$ \\
\hline Weather station & $5 \mathrm{~s}$ & $\begin{array}{l}\text { Air temperature, } \mathrm{RH}, \\
\text { solar irradiance, pre- } \\
\text { cipitation, wind speed } \\
\text { \& direction }\end{array}$ & Data logger polled every $60 \mathrm{~min}$ & & $\begin{array}{l}\text { Monitor precipitation; } \\
\text { Data for CWSI calcu- } \\
\text { lations }\end{array}$ \\
\hline
\end{tabular}


crop canopy. Three MBRs were positioned in furrows in the highest irrigation treatment amounts $\left(\mathrm{I}_{80 \%}\right)$ at the beginning of the growing season and joined to the WSN.

\section{Wireless Sensor Network}

The general components of the WSN were an embedded or base station computer, network coordinator, routers, and sensor nodes. The base station (Ampro Adlink Technology, San Jose, Calif.) was powered using $120 \mathrm{~V} \mathrm{AC}$ and located at the pivot point. It functioned to collect, store, and process data from the weather station and the wireless sensor nodes, and to control pivot movement for site-specific irrigation management using an RS232 serial link to the pivot control panel. The base station was also equipped with a $900 \mathrm{MHz}$ spread spectrum radio (model RF430, Campbell Scientific, Logan Utah) to communicate with the weather station (CR1000 datalogger, Campbell Scientific, Logan, Utah), and a XBee Series 2 radio frequency (RF) module configured as a coordinator. An average integrated CWSI (Jackson et al., 1981) was calculated for each treatment plot after the pivot moved across the field. Pivot movement and irrigation control for both automatic and manual irrigations were managed by the base station using ARS-developed software. Manual irrigation amounts were directly placed into the ARS pivot-control software using an embedded graphical user interface on odd days of the year (DOY).

The WSN was established as a mesh network using the 802.15.4 communication standard (IEEE Std. 802.15.4f, 2011) with Zigbee stack. An Xbee Series 2 module was configured as a coordinator using firmware from the manufacturer (Digi International, Minnetonka, Minn.) and was outfitted with a $15 \mathrm{dBi}$ omnidirectional antenna. The coordinator maintained the designated operational frequency channel within the $2.4 \mathrm{GHz}$ ISM (Industrial Scientific Medical) band and the 16-bit personal area network identification (PAN ID) when powered. At startup, the coordinator allowed routers and sensor nodes preconfigured with the same PAN ID to join the network. Once joined, the routers also functioned as transceivers. Both the coordinator and routers were continuously powered. Each sensor node was capable of self-discovering the network by ad-hoc association with either the coordinator or a router when cycling out of its sleep mode. When joined to the network, the microprocessor of the sensor node initiated data throughput via the RF module. Data were transmitted using multiple pathways established autonomously between nodes (either routers and/or other sensor nodes). The radio software handled error detection and retries automatically following transmission.

Routers were added to the WSN to facilitate connectivity of the 'waking nodes' to the network and to act as transceivers. Three routers were mounted to the top-side of the pivot lateral in the middle of spans 2,3 , and $4(74,105$, and $155 \mathrm{~m}$ from the pivot point). Two additional routers were located in the field inside the first concentric plot at the borders of the Auto I and Manual II, and the Auto II and Manual III sectors. The GPS node, located at the end tower, was also configured as a router. Field routers were positioned to maintain a minimum link margin of $20 \mathrm{dBm}$ to the coordinator (table 2 ). Link margins between routers and other network devices were calculated as: link margin= Transmitted power $(\mathrm{dBm})+$ Antenna Gain $(\mathrm{dBm})+$ Receiver Sensitivity $(\mathrm{dBm})-$ Equipment Loss $(\mathrm{dBm})$ - Path Losses $(\mathrm{dBm})$, where path losses were estimated from the Friis equation (Balanis, 2005) and the Fresnel zone equation as discussed by Tate et al. (2008).

There were 24 IRTs on the pivot lateral that allowed for continuous crop canopy temperature monitoring as the pivot moved across the field, while six IRTs in the field provided reference crop canopy temperature for a well-watered canopy.

\section{Irrigation Scheduling}

Sorghum bicolor, (L.) Moench, variety $\mathrm{NC}+5 \mathrm{C} 35$, was planted in concentric rows, $0.76 \mathrm{~m}$ apart on DOY 180 (29 June) at a plant density of 20 plants $\mathrm{m}^{-2}$. Irrigations for three alternating sectors within the field were automatically scheduled based on an integrated crop water stress index (CWSI) calculated every min. over daylight hours using data from the IRTs and radiometer sensors and averaged over the $\mathrm{I}_{80 \mathrm{~A}} \%$ plots. The threshold value to trigger irrigations over the $\mathrm{I}_{80 \% \mathrm{~A}}$ plots was set at 300 (CWSI-days). The threshold value was determined from meteorological data and crop canopy temperature measurements collected over well -irrigated grain sorghum in 2009 and 2010 at Bushland, Texas. The integrated CWSI was based on the theoretical approach developed by Jackson et al. (1981; 1988). These calculations were thoroughly detailed by O'Shaughnessy et al. (2012b). When triggered, 80\%, 50\%, $30 \%$, and $0 \%$ of twice the daily peak crop water use $(2 \times 10$ $\mathrm{mm}=20 \mathrm{~mm})$, designated $\mathrm{I}_{80 \mathrm{~A} \%}, \mathrm{I}_{50 \mathrm{~A} \%}, \mathrm{I}_{30 \mathrm{~A} \%}$, and $\mathrm{I}_{0 \mathrm{~A} \%}$, was applied to specific plots within the automatic sectors. Because irrigations were scheduled every other day, the irrigation level for automatic treatments in the automatic treatments were $80 \%, 50 \%, 30 \%$, and $0 \%$ of twice the crop's peak daily ET rate $(16,10,6$, and $0 \mathrm{~mm})$ so that irrigations could replenish water used by the crop even during the peak water use period (O'Shaughnessy et al., 2011c). Daily peak water use was determined from sorghum data grown at Bushland, Texas.

Manual irrigations were scheduled 2-3 days during a 7 day period on odd-numbered DOY. Irrigation amounts applied to manual treatment plots were based on $80 \%$, $50 \%, 30 \%$, and $0 \%$ (designated $\mathrm{I}_{80 \% \mathrm{M}}, \mathrm{I}_{50 \% \mathrm{M}}, \mathrm{I}_{30 \% \mathrm{M}}$, and $\mathrm{I}_{0 \% \mathrm{M}}$, respectively) of full replenishment of soil water depletion to field capacity in the top $1.5 \mathrm{~m}$ of soil as measured weekly with the neutron probe (NP) using methods described by Evett (2008). Pivot control was automated using ARS software code (Peters and Evett, 2008). The experiment was initiated on an odd DOY, whereby a manual irrigation was scheduled after averaging soil water content readings taken from the $\mathrm{I}_{80 \% \mathrm{M}}$ treatment plots. On odd DOY, manual pie-sections I, II, and III were irrigated with

Table 2. Estimated link margin amounts between critical nodes.

\begin{tabular}{lcc}
\hline \multicolumn{1}{c}{ Minimum Distances } & $\begin{array}{c}\text { Distance } \\
(\mathrm{m})\end{array}$ & $\begin{array}{c}\text { Link Margin } \\
(\mathrm{dBm})\end{array}$ \\
\hline IRT sensor node to IRT sensor node & 15 & 33 \\
Pivot lateral router1 to coordinator & 74 & 24 \\
IRT sensor to field router & 49 & 20 \\
Field router to coordinator & 100 & 21 \\
\hline
\end{tabular}


varying irrigation depths applied concentrically using the VRI system. When the pivot crossed into an automatic piesection, irrigation was withheld and the pivot speed was increased until it approached the next manual pie-section. Data captured from the IRTs, while the pivot traveled over the automatic pie-sections on odd DOY were used to evaluate crop water stress in the automatic treatment plots.

If on an odd DOY, the average threshold of the $\mathrm{I}_{80 \mathrm{~A}} \%$ plots was surpassed, an accumulation register was incremented. If on the next even DOY, the average threshold value for the $\mathrm{I}_{80 \% \mathrm{~A}}$ plots was not surpassed but the accumulation register $>0$ (a trigger value was stored), then irrigation of the automatic control plots was scheduled (fig. 3), and the accumulation register was reduced by 1 . The subroutine to increment or decrement the accumulation register will be referred to as a "banking system."
Water USE ANd Water USE EFFiciency Calculations

Crop water use $\left(\mathrm{ET}_{\mathrm{c}}, \mathrm{mm}\right)$ was calculated using the soil water balance equation:

$$
\mathrm{ET}_{\mathrm{c}}=P+I+F-\Delta S-R
$$

where $\Delta S$ is the change in soil water stored in the profile as determined using the neutron probe (NP) method (final minus initial soil water reading), $R$ is runoff, $P$ is precipitation, $I$ is the irrigation water applied, and $F$ is flux across the lower boundary of the control volume (taken as positive when entering the control volume), all in units of $\mathrm{mm}$. Runoff and percolation were assumed to be negligible because the field was furrow diked, plots were large enough that horizontal fluxes were important only in plot borders, and NP measurements indicated negligible flux at the 2.1 to $2.3 \mathrm{~m}$ depth range.

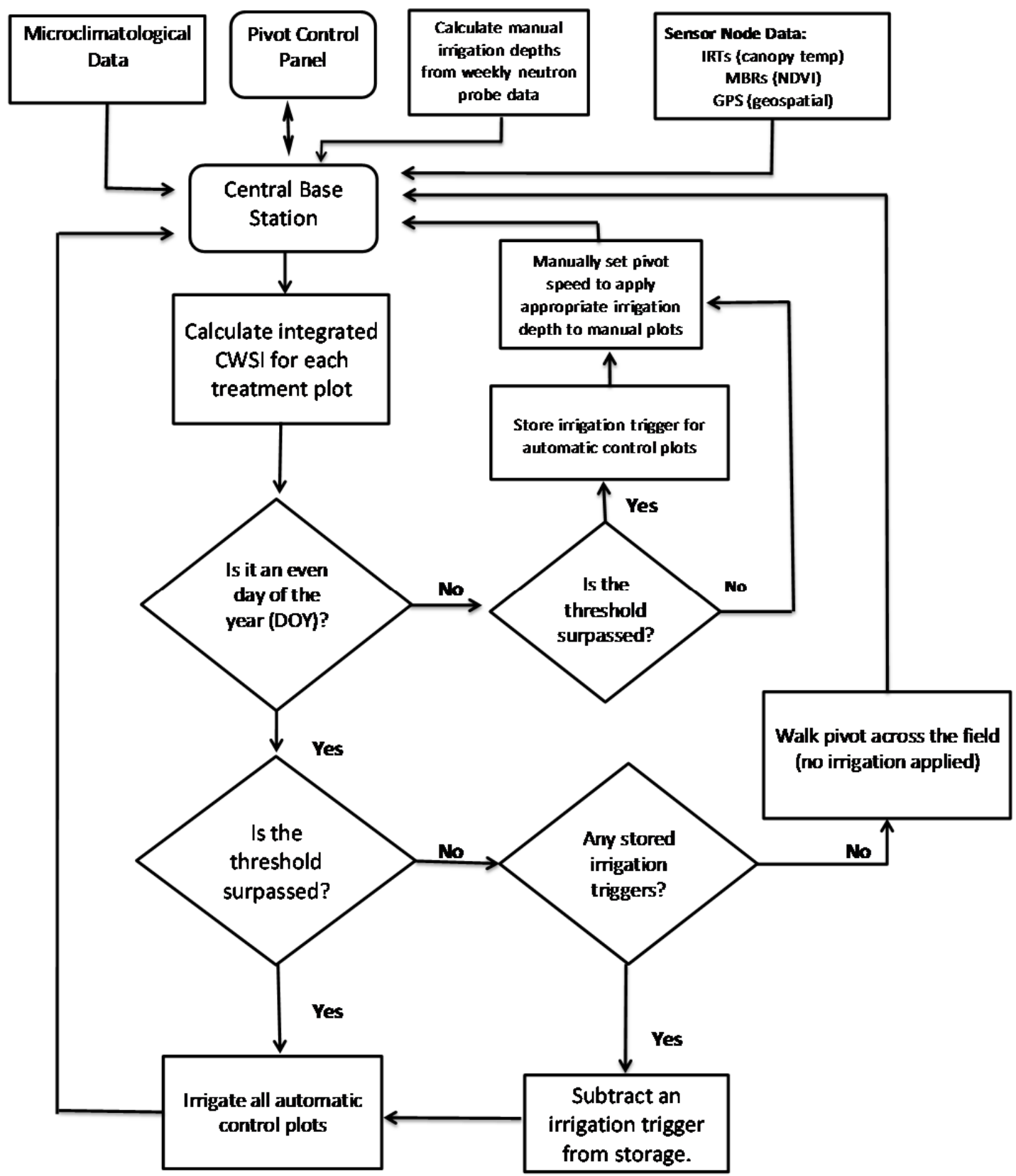

Figure 3. Flow chart summarizing wireless sensor network for irrigation scheduling (manual and automatic methods) and pivot control. 
Pivot control and irrigation management were accomplished using Visual Basic in Microsoft Visual Studio 2010 (Microsoft, Ver.4.0) as the IDE. The base-station was accessed remotely from the laboratory by a wireless Ethernet connection (5.8 GHz band). Because the pivot was moving when canopy temperature measurements were obtained, the center pivot passed over each plot during different times of the day, requiring a method to determine canopy temperature, $T_{\mathrm{s}}$, throughout the daylight hours for each remote measurement. We used the scaling procedure described by Peters and Evett (2004):

$$
T_{s}=T_{e}+\frac{\left(T_{r m t, t}-T_{e}\right)\left(T_{r e f}-T_{e}\right)}{T_{r e f, t}-T_{e}}
$$

where $T_{\mathrm{e}}\left({ }^{\circ} \mathrm{C}\right)$ was the predawn canopy temperature; $T_{\text {ref }}$ $\left({ }^{\circ} \mathrm{C}\right)$ was the reference canopy temperature at the same time interval as $T_{\mathrm{s}}\left({ }^{\circ} \mathrm{C}\right) ; T_{\mathrm{rmt}, \mathrm{t}}$ was the one-time-of-day canopy temperature measurement at the plot (remote location, denoted by subscript rmt) at any daylight time $t$ measured by the IRTs on the pivot lateral; and $T_{\mathrm{ref}, \mathrm{t}}\left({ }^{\circ} \mathrm{C}\right)$ was the measured reference temperature (average in the $\mathrm{I}_{80 \mathrm{~A}}$ ) for the time $t$ that the plot (remote) temperature measurement was taken. The diel (24 h) $T_{\text {ref,t }}$ was obtained using stationary IRTs mounted on fixed masts in the $\mathrm{I}_{80 \% \mathrm{~A}}$ irrigated treatment plots. This scaling method has been used in automatic irrigation scheduling studies using a center pivot for cotton (O'Shaughnessy and Evett, 2010a), soybean (Peters and Evett, 2008), and sorghum (O'Shaughnessy et al., 2012a; 2012b).

\section{Agronomics and NDVI Calculations}

Biomass and leaf area index (LAI) determinations were made from the automatic and manual control treatment plots at critical growth stages throughout the season. Destructive plants samples were taken from a $1.5 \mathrm{~m}^{2}$ area on DOY $(200,214,228,251)$ and leaf area was determined using a bench top leaf area meter (model LI-3100, LICOR, Lincoln, Nebr.).

Although the MBRs contained four photodiode detectors, for the purposes of this study, the normalized difference vegetative index, NDVI, was the only VI calculated. Calculations were made from using the reflectance measurements in the NIR and Red regions, designated $\mathrm{NIR}_{\rho}$ and $\operatorname{Red}_{\rho}$, respectively. The NDVI was calculated using the equation by Rouse et al. (1973):

$$
N D V I=\frac{\left(N I R_{\rho}-\operatorname{Re} d_{\rho}\right)}{\left(N I R_{\rho}+\operatorname{Re} d_{\rho}\right)}
$$

Water use efficiency (WUE; $\mathrm{kg} \mathrm{m}^{-3}$ ) was calculated as:

$$
W U E=\frac{Y_{g}}{E T_{c}}
$$

where $Y_{\mathrm{g}}$ is the economic yield $\left(\mathrm{g} \mathrm{m}^{-2}\right)$ (Viets, 1962).

\section{Network Troubleshooting}

Remote monitoring and maintenance of the WSN and the center pivot system were accomplished through an ethernet connection to the embedded computer. Graphical user interfaces facilitated rapid monitoring of IRT readings and battery voltage levels (fig. 4). Each morning the status of the network was viewed and batteries were replaced if they were low. Troubleshooting in the field required the use of a digital voltmeter, a laptop, and a serially linked XBee RF module configured as a router with the same PAN ID of the coordinator and a "no-join" configuration. This troubleshooting protocol was useful for determining which sensors were associated with the WSN after the immediate deployment or re-boot of the network system.

Transmission performance was quantified by calculating the percent packet delivery rate (PPDR) (Li et al., 2010) as:

$$
P P D R=\frac{N_{r}}{N_{t}} \times 100 \%
$$

where $\mathrm{N}_{\mathrm{r}}$ is the number of packets received by the base station, and $\mathrm{N}_{\mathrm{t}}$ is the number of packets transmitted by the sensor node.

\section{STATISTICAL ANALYSIS}

Results were analyzed using the Mixed Models procedure (Littell et al., 2006) with statistical software (SAS 9.2, SAS Institute Inc., Cary, N.C.). The main factors of irrigation method (automatic and manual), and irrigation treatment amount $(80 \%, 50 \%, 30 \%, 0 \%)$ were treated as fixed effects. Random effects included sectors and concentric plots. Differences among means of fixed effects were tested using least square means within each irrigation level and $p$ values were adjusted for multiplicity with the Tukey-Kramer test $(p \leq 0.05)$. Denominator degrees of freedom were approximated by the Satterthwaite method. The SAS model estimated variance components using restricted maximum likelihood (REML).

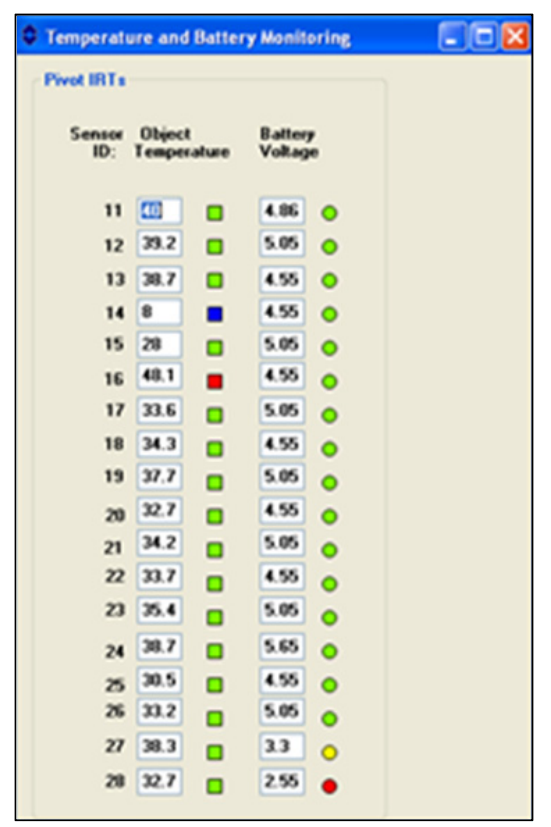

Figure 4. Graphical user interface indicating object temperature reading and battery voltage levels from infrared thermometers on the pivot lateral. Green indicates readings within acceptable range, blue indicates under range, red indicates over range, and yellow indicates a marginal value. 


\section{RESULTS AND DISCUSSION}

Microclimatological data were collected throughout the growing season (table 3 ) and were merged at midnight with canopy temperature data to calculate an average integrated crop water stress index for each treatment plot. The 2011 growing season was extremely dry (driest season of record, 1939-2012) with growing season rainfall totaling less than $9 \mathrm{~mm}$. During the past five years, the average rainfall during this same time period, from May through October at Bushland, Texas, was $246 \mathrm{~mm}$.

\section{Network Performance and Maintenance}

With the exception of two days, the WSN operated continuously, $24 \mathrm{~h} \mathrm{~d}^{-1}$ throughout the 2011 growing season. When non-operational, the fault was due to the antenna cable working itself loose from the coordinator XBee RF module at the circuit board level. The PPDR for each of the IRT sensor nodes ranged from $90 \%$ to $95 \%$. The typical distance between stationary neighboring sensors was $35 \mathrm{~m}$. The PPDR for IRTs on the lateral ranged from $93 \%$ to $98 \%$. The maximum distance between IRTs on the lateral was $15 \mathrm{~m}$. The sensors with the lowest PPDR suffered from power issues-either loose power connections to the sensor board or solar panel (sensors \#24, \#26, and \#28). The PPDR for the MBRS was $98 \%$. Minimal data dropout occurred relative to the IRTs; this was likely due to the lesser amount of data transmitted and therefore, less potential for dropout due to data collision at the base station.

Crop Canopy Temperature and Average Integrated CWSI

After two weeks of irrigation treatments, differences in average plant canopy temperature among the irrigation treatments in the automatic plots $\left(\mathrm{I}_{80 \mathrm{~A} \%}, \mathrm{I}_{50 \mathrm{~A} \%}, \mathrm{I}_{30 \mathrm{~A} \%}\right.$, and $\left.\mathrm{I}_{0 \mathrm{~A} \%}\right)$ were obvious from graphs of canopy temperatures taken over plots 13-24, (Auto I, fig. 1). The average crop canopy temperature for the most deficit irrigated treatment plots, $\mathrm{I}_{0 \mathrm{~A}} \%$ and $\mathrm{I}_{30 \mathrm{~A} \%}$ had greater temperatures than those irrigated at $\mathrm{I}_{50 \mathrm{~A} \%}$ and $\mathrm{I}_{80 \mathrm{~A} \%}$ from approximately 10:00 a.m. until 7:00 p.m. (fig. 5). Average canopy temperatures from these plots were also greater than air temperature for approximately $7 \mathrm{~h}$ during the daytime. Solar irradiance and ambient air temperature were plotted to provide a reference for temperature variations throughout the day. The negative linear relationship between canopy temperature and irrigation treatment amounts $\left(T_{\mathrm{c}_{\mathrm{i}} \mathrm{i}}=-0.035 i+28.1\right)$ where $T_{\mathrm{c}}$ was the average canopy temperature for each irrigation treatment level $i(80 \%, 50 \%, 30 \%, 0 \%)$. A negative linear relationship between canopy temperature and irrigation treatment levels was also described by Lamm and Aiken (2008). Variations in temperature and solar irradiance were due to variations in cloud cover during the day.
The average integrated CWSI (iCWSI), calculated for each plot for every day that the pivot moved across the field, was 339/337, 407/399, 457/451, and 598/602 (CWSIdays) for the $\mathrm{I}_{80 \%}, \mathrm{I}_{50 \%}, \mathrm{I}_{30 \%}$, and $\mathrm{I}_{0 \%}$ manual/automatic treatment levels, respectively. Linear regression analysis indicated a negative linear correlation between these seasonal average stress threshold levels and dry grain yields, Yield $=-0.02 i C W S I+12.3$, (fig. 6). The negative linear relationship between this thermal stress index and crop yields was similar to those reported by O'Shaughnessy et al. (2011c) using wired IRTs and an empirical CWSI for soybean and cotton. The greatest standard deviation among mean iCWSI thresholds occurred in the $\mathrm{I}_{0 \%}$ treatment level. Many plants in this treatment failed to thrive and did not produce a grain yield because of the exceptional drought conditions. Although, there were differences among average iCWSI values for automatic and manual irrigation treatment plots, this variation could be explained by random effects of concentric plots and sectors or spatial variability. Another anomaly associated with crop canopy monitoring using IRTS mounted on a center pivot was that IRTs located on the inner spans had a higher sampling rate per area viewed than those located on the outer spans. This was because the outer spans traveled faster than the inner spans. A paired two-tailed t-test analysis of the mean plot temperature among concentric plots of the same irrigation rate were not significantly different over five separate days (data not shown) when the pivot moved.Spectral Reflectance and LAI.

The NDVI values were calculated every 5 days (using the MBRS) from 11:00 to 15:30, and plotted against DOY for the 2011 growing season (fig. 7a). The four destructive LAI measurements were positively correlated to the NDVI values measured by the wireless MBRs on the same day as the destructive sampling (fig. 7b). Inconsistencies in the NDVI values may be due to wind impacting the amount of vegetation within the sensor's field of view (FOV), differences between destructive sampling and MBR locations, or variable cloud cover over the duration of the calculated period.

\section{Irrigation Scheduling and the Integrated CWSI}

There was a $5 \%$ difference in cumulative irrigation amounts applied between the manual and automatic scheduling methods ( $383 \mathrm{~mm}$ applied to the $\mathrm{I}_{80 \mathrm{M}}$, and $402 \mathrm{~mm}$ applied to the $\mathrm{I}_{80 \mathrm{~A}}$ treatment plots). Two stored irrigations were delivered on DOY 256 and 262 to the automatic sectors based on the "banking" system described earlier. These dates were between the soft and hard dough stages (data not shown).

Table 3. Climatic data ${ }^{[a]}$ for each month of growing season 2011 in Bushland, Texas.

\begin{tabular}{cccccccc}
\hline Month & $\begin{array}{c}\mathrm{T}_{\min }{ }^{[b]} \\
\left({ }^{\circ} \mathrm{C}\right)\end{array}$ & $\begin{array}{c}\mathrm{T}_{\max } \\
\left({ }^{\circ} \mathrm{C}\right)\end{array}$ & $\begin{array}{c}\mathrm{RH}_{\min } \\
(\%)\end{array}$ & $\begin{array}{c}\mathrm{RH}_{\max } \\
(\%)\end{array}$ & $\begin{array}{c}\text { Total Precip } \\
(\mathrm{mm})\end{array}$ & $\begin{array}{c}\text { Solar Radiation } \\
\left(\mathrm{MJ} \mathrm{m}^{-2}\right)\end{array}$ & $\begin{array}{c}\mathrm{ET}_{\mathrm{o}} \\
\left(\mathrm{mm} \mathrm{d}^{-1}\right)\end{array}$ \\
\hline May & -0.8 & 38.7 & 18.0 & 92.9 & 1.1 & 30.5 & 9.8 \\
June & 15.4 & 31.3 & 23.1 & 87.6 & 2.1 & 30.4 & 7.1 \\
July & 16.7 & 32.2 & 28.1 & 85.9 & 2.1 & 27.7 & 7.3 \\
Aug & 16.2 & 31.4 & 27.8 & 85.2 & 1.6 & 23.9 & 6.7 \\
Sept & 10.9 & 26.5 & 30.2 & 88.2 & 0.4 & 20.3 & 4.9 \\
Oct & 4.0 & 18.8 & 37.8 & 88.8 & 1.3 & 17.6 & 3.3 \\
\hline
\end{tabular}

[a] Reference evapotranspiration ( $\left(\mathrm{ET}_{\mathrm{o}}\right.$ ) data for grass from the Texas High Plains Evapotranspiration (TXHPET) Network

[b] $\mathrm{T}_{\min }=$ minimum air temperature; $\mathrm{T}_{\max }=$ maximum air temperature; $\mathrm{RH}_{\min }=$ minimum relative humidity; $\mathrm{RH}_{\max }=$ maximum relative humidity. 


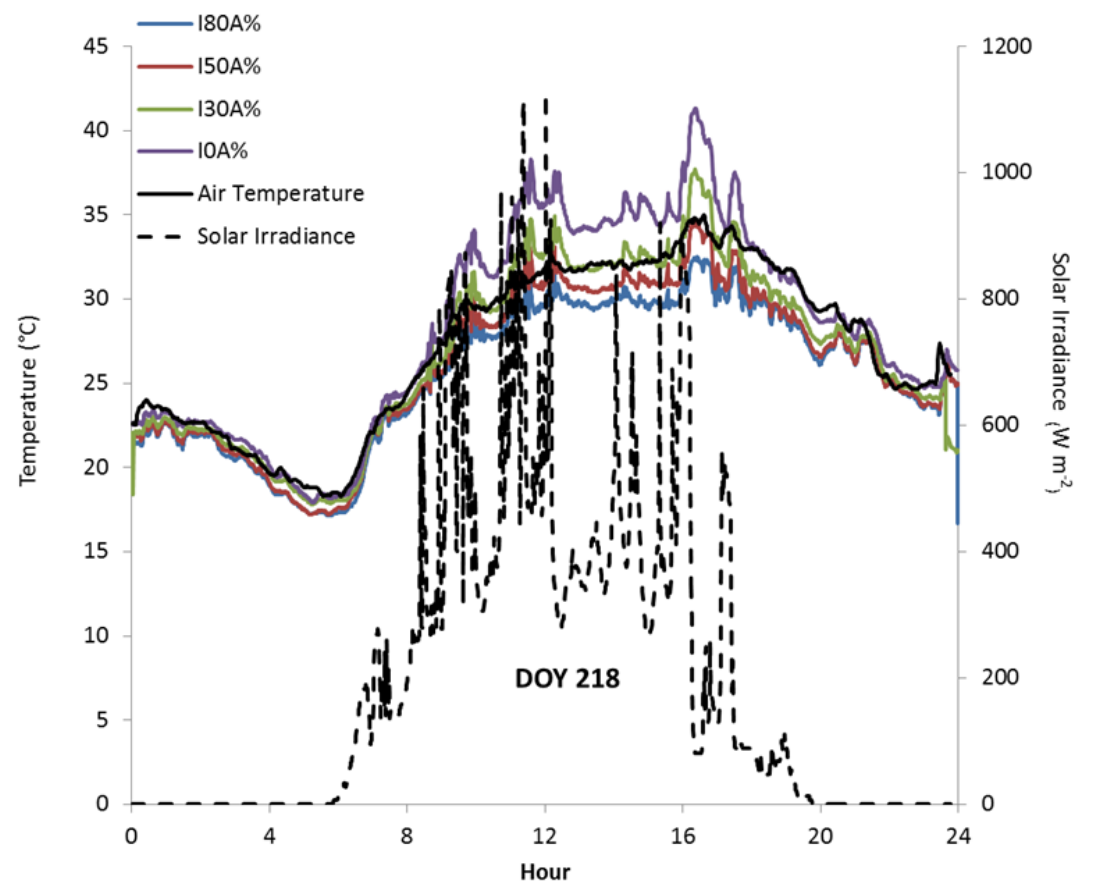

(a)

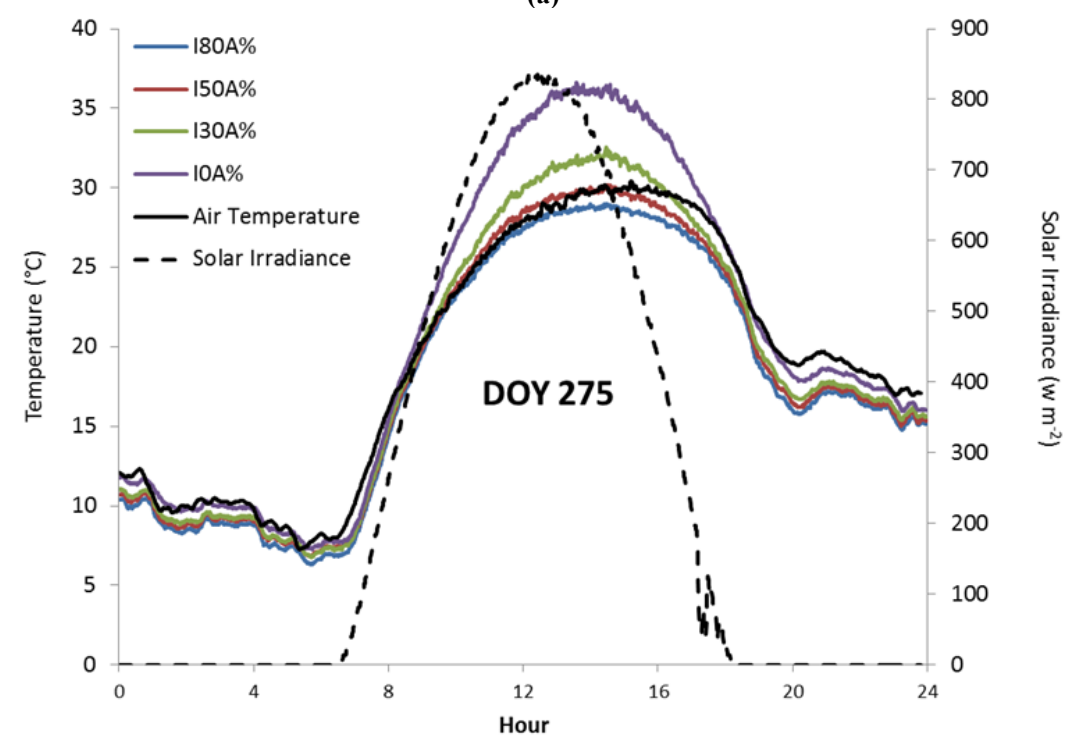

(b)

Figure 5. Average crop canopy temperature readings over automatic sector II, plots 13-24, on: (a) cloudy DOY 218 ; and (b) on clear DOY 275. This was towards the end of the irrigation season and the pivot lateral was parked over this sector for a $24 \mathrm{~h}$ period.

\section{Crop Responses}

Average dry grain yields and crop WUE over all four irrigation levels were not significantly different between manual and automatic scheduling methods. For $\mathrm{ET}_{\mathrm{c}}$ among irrigation treatment levels, the differences between methods were not significant except at the $\mathrm{I}_{50 \mathrm{~A}}$ \% irrigation amount where $\mathrm{ET}_{\mathrm{c}}$ was significantly greater. Although not significantly different from the $\mathrm{I}_{80 \mathrm{~A} \%}$, mean dry grain yields $(0.65$ $\left.\mathrm{kg} \mathrm{m}^{-2}\right)$ and mean WUE $\left(1.33 \mathrm{~kg} \mathrm{~m}^{-3}\right)$ were largest in the $\mathrm{I}_{80 \mathrm{M} \%}$ irrigation treatment plots (table 4). The application of higher irrigation amounts in the automatic plots, suggests that the plant feedback algorithm could be improved. Changes could include correction of the IRT temperature data when canopy cover is less than full which should elim- inate any false positive irrigation signals early in the growing season. The "banking system" appeared to initiate irrigation when it was unnecessary, i.e. when the crop was nearing the hard dough stage. Revisions to the "banking system" could include feedback from MBRs indicating maturing grain status, and therefore the decision to withhold irrigation could be made.

Crop response, from the same variety of sorghum grown in Bushland, Texas, in 2009, showed that the largest mean dry grain yields $\left(0.81\right.$ and $\left.0.80 \mathrm{~kg} \mathrm{~m}^{-2}\right)$ were produced in the automatic and manual $\mathrm{I}_{80 \%}$ treatment plots, respectively. However, the largest mean WUE $\left(2.04 \mathrm{~kg} \mathrm{~m}^{-3}\right)$ resulted in $\mathrm{I}_{55 \mathrm{~A} \%}$ treatment plots. The automatic scheduling algorithm was a CWSI and time threshold method (O'Shaughnessy et al., 2012b). In 2010, the largest mean dry grain yields 


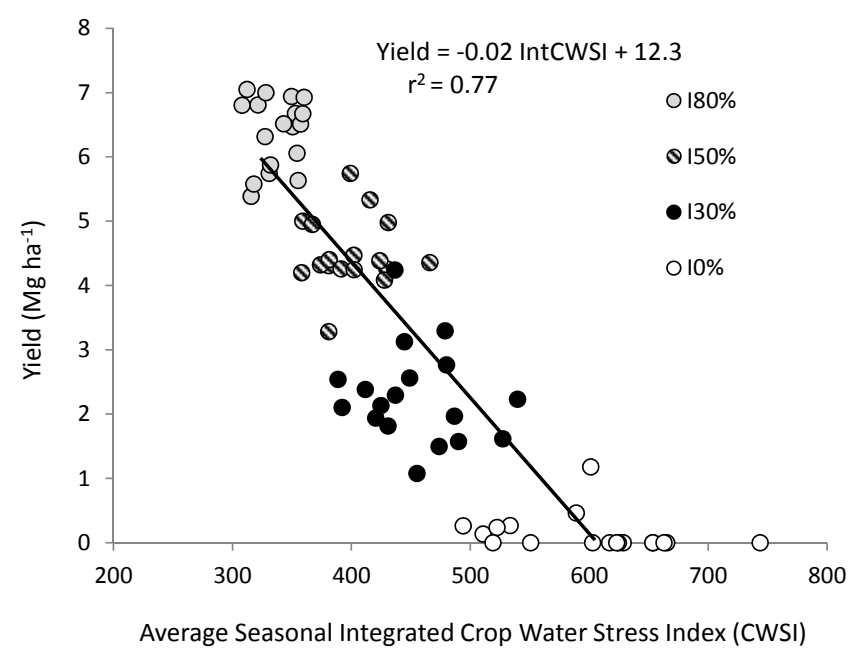

Figure 6. Average seasonal integrated crop water stress index (i $C$ WSI) for grain sorghum irrigated at levels of $\mathbf{I}_{80 \%}, \mathbf{I}_{50 \%}, \mathbf{I}_{30 \%}$ and $\mathbf{I}_{\mathbf{0}}$ for both irrigation methods.

were similar to those in 2011, with yields of 0.71 and $0.63 \mathrm{~kg} \mathrm{~m}^{-2}$ produced in the automatic and manual $\mathrm{I}_{80} \%$ treatment plots, respectively. Dry grain yields at this level were not significantly different between methods. The largest mean WUE was in $\mathrm{I}_{55 \mathrm{~A} \%}$ treatment plots $\left(1.32 \mathrm{~kg} \mathrm{~m}^{-3}\right)$. In 2010, the soil water profile was nearly at field capacity prior to planting due to a late spring snowfall. The automatic scheduling algorithm was the Time Temperature Threshold method (O'Shaughnessy et al., 2012a). The greatest differences between dry grain yield and WUE between growing seasons (2011 vs. 2009 and 2010) occurred in the higher deficit irrigation treatment levels $\left(\mathrm{I}_{30 \%}\right.$ and the $\left.\mathrm{I}_{0 \%}\right)$, whereby dry grain yields for 2011 were at least $47 \%$ and 91\% less than in 2009 and 2010, respectively. Similarly, WUE in 2011 were at least $36 \%$ and $89 \%$ less than in 2009 and 2010 , in the $\mathrm{I}_{30 \%}$ and $\mathrm{I}_{0 \%}$ treatment plots, respectively. Extreme drought conditions were responsible for this striking impact on these deficit irrigation treatments.
In 2011, both the manual and automatic methods of irrigation scheduling controlled dry grain WUE levels. Irrigation applied in this graph does not include pre-plant irrigation amounts, since automatic methods were not initiated until after the plant stand was established. Although, WUE values tended to increase as irrigation amounts increased, the rate of dry grain yield per irrigation applied decreased between the $\mathrm{I}_{50 \%}$ and $\mathrm{I}_{80 \%}$ as compared to the rate between the $\mathrm{I}_{30 \%}$ and $\mathrm{I}_{50 \%}$ irrigation treatment levels (fig. 8). In 2009 and 2010, WUE for dry grain yields of the same variety declined from the $\mathrm{I}_{55 \%}$ to the $\mathrm{I}_{80 \%}$ irrigation treatment level (O'Shaughnessy et al., 2012a; 2012b). The control of crop WUE using automatic irrigation scheduling was also demonstrated for corn by Evett et al. (2002), for cotton by O'Shaughnessy and Evett (2010b), and for grain sorghum (O’Shaughnessy et al., 2012a; 2012b).

Table 4. Sorghum yield response to automatic irrigation scheduling based on an integrated CWSI threshold and manual irrigation based on soil water sensing for the 2011 growing season, Bushland, Texas.

\begin{tabular}{|c|c|c|c|}
\hline & $\begin{array}{l}\text { Grain Yield } \\
\left(\mathrm{kg} \mathrm{m}^{-2}\right)^{[\mathrm{a}]}\end{array}$ & $\begin{array}{c}\mathrm{ET}_{\mathrm{c}} \\
(\mathrm{mm})\end{array}$ & $\begin{array}{c}\text { WUE } \\
\left(\mathrm{kg} \mathrm{m}^{-3}\right)\end{array}$ \\
\hline \multicolumn{4}{|c|}{ Irrigation Method } \\
\hline Manual & $0.34 \mathrm{a}$ & $334 a$ & $0.86 \mathrm{a}$ \\
\hline \multirow[t]{2}{*}{ Auto } & $0.33 \mathrm{a}$ & $350 \mathrm{a}$ & $0.77 \mathrm{a}$ \\
\hline & $\begin{array}{l}F=0.74 \\
p=0.44\end{array}$ & $\begin{array}{l}F=3.5 \\
p=0.14\end{array}$ & $\begin{array}{l}\mathrm{F}=4.9 \\
\mathrm{p}=0.09\end{array}$ \\
\hline \multicolumn{4}{|c|}{ Irrigation Treatment Amount } \\
\hline $80 \%$ & $0.64 \mathrm{a}$ & $503 a$ & $1.28 \mathrm{a}$ \\
\hline $50 \%$ & $0.45 b$ & $382 b$ & $1.18 \mathrm{a}$ \\
\hline $30 \%$ & $0.23 \mathrm{c}$ & $319 \mathrm{c}$ & $0.71 b$ \\
\hline \multirow[t]{2}{*}{$0 \%$} & $0.01 \mathrm{~d}$ & $190 d$ & $0.07 \mathrm{c}$ \\
\hline & $\begin{array}{l}F=125.2 \\
p<0.001\end{array}$ & $\begin{array}{c}F=330, \\
p<0.0001\end{array}$ & $\begin{array}{l}\mathrm{F}=292.9, \\
\mathrm{p}<0.0001\end{array}$ \\
\hline \multicolumn{4}{|c|}{ Irrigation Treatment X Method } \\
\hline Manual 80\% & $0.65 a$ & $492 a$ & $1.33 \mathrm{a}$ \\
\hline Auto $80 \%$ & $0.63 \mathrm{a}$ & $517 \mathrm{a}$ & $1.25 \mathrm{a}$ \\
\hline Manual $50 \%$ & $0.44 \mathrm{~b}$ & $355 \mathrm{c}$ & $1.22 \mathrm{a}$ \\
\hline Auto $50 \%$ & $0.46 \mathrm{~b}$ & $409 \mathrm{~b}$ & $1.11 \mathrm{ab}$ \\
\hline Manual 30\% & $0.25 \mathrm{c}$ & $312 d$ & $0.78 b$ \\
\hline Auto $30 \%$ & $0.21 \mathrm{c}$ & $325 \mathrm{c}, \mathrm{d}$ & $0.65 b$ \\
\hline Manual 0\% & $0.02 \mathrm{~d}$ & $195 \mathrm{e}$ & $0.11 \mathrm{c}$ \\
\hline \multirow[t]{2}{*}{ Auto $0 \%$} & $0.01 \mathrm{~d}$ & $185 \mathrm{e}$ & $0.04 \mathrm{c}$ \\
\hline & $\begin{array}{c}F=0.83 \\
p=0.48\end{array}$ & $\begin{array}{c}F=5.6 \\
p<0.002\end{array}$ & $\begin{array}{c}\mathrm{F}=0.18 \\
\mathrm{p}=0.91\end{array}$ \\
\hline
\end{tabular}
effects were not significantly different.

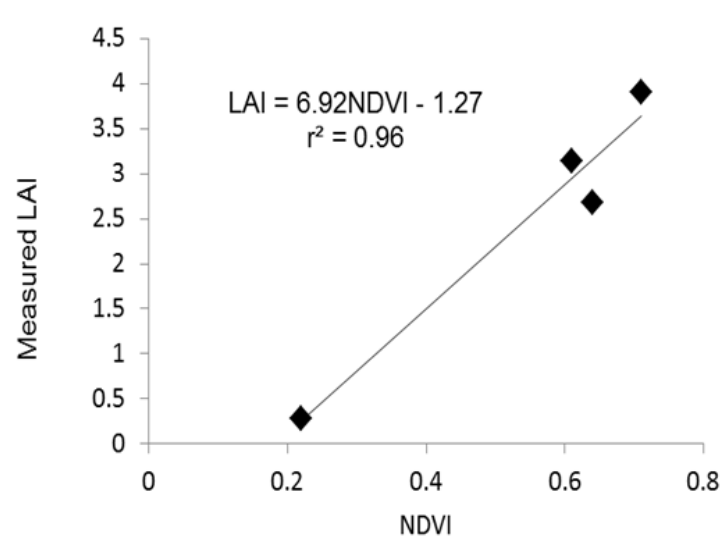

Figure 7. Calculated NDVI plotted: (a) against DOY; and (b) against LAI measurements taken in the $\mathbf{I}_{80 \%}$ automatic plots over the growing season. 
Automatic irrigation scheduling in this study was based on a threshold value for the $\mathrm{I}_{80 \mathrm{~A} \%}$ plots. In future research, the average annual integrated CWSI calculated for each irrigation treatment amount when the pivot moved across the field [338 $\left(\mathrm{I}_{80 \%}\right), 403\left(\mathrm{I}_{50 \%}\right)$, and $\left.454\left(\mathrm{I}_{30 \%}\right)\right]$ will serve as threshold set points for irrigation scheduling and controlling WUE by managing irrigation for individual treatment plots. Future work will also couple remote spatiotemporal crop water stress monitoring with the control of VRI equipment by daily automated prescription map building for site-specific irrigation delivery. Forthcoming work will also focus on alternative decision support algorithms for irrigation scheduling to provide a real-time estimate of daily $\mathrm{ET}_{\mathrm{c}}\left(\mathrm{ET}_{\mathrm{o}}\right.$, reference evapotranspiration $\mathrm{x} \mathrm{K}_{\mathrm{c}}$, specific crop coefficient) for irrigation decision making in situations when the pivot does not move across the field or during continuous periods of cloudy conditions. These alternative decision support algorithms will include NDVI values calculated from spatially distributed wireless MBRs.

Finally, there are management limitations to applying this algorithm for commercial application, mainly calculation of the $i C W S I$ during daylight hours only, and a high repeat temporal frequency of data over the same area. The expectation for a commercialized system is to collect data forward of a moving and irrigating center pivot system. The travel time for a production center pivot sprinkler to irrigate a full circle could be greater than 7 days, sensor measurements for an entire production field will have a lesser repeat frequency than used in this study. However, it would be possible to adjust the $i C W S I$ algorithm and decision-making using data collected less frequency from the WSN system. A feasible next step would be to evaluate the effectiveness of irrigation management and crop response using a repeat frequency of 3.5 days over one-half of a center pivot field. Under conditions of drought or limited well capacity, it is common for producers to plant half of a pivot circle.

\section{CONCLUSION}

This study was a primary step towards commercialization of a plant-sensing network for site-specific irrigation

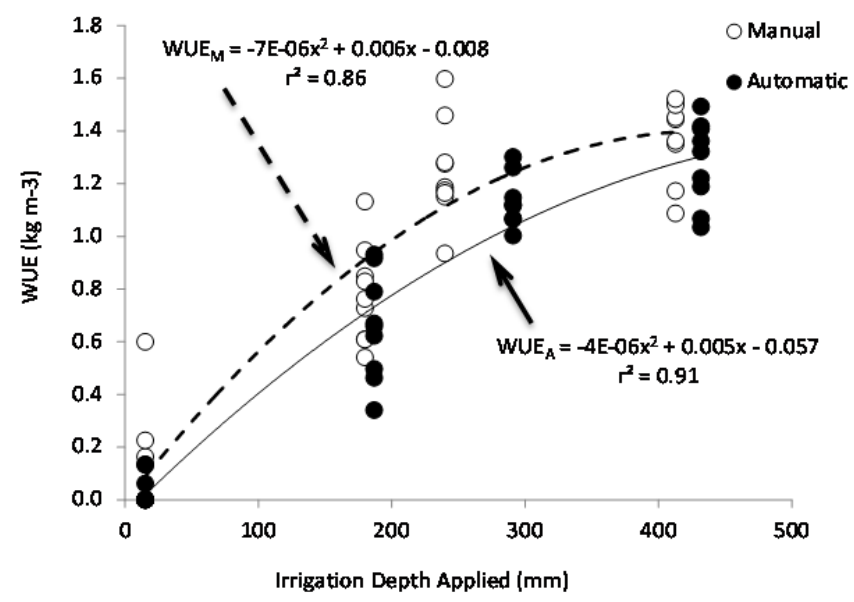

Figure 8. Relationship between water use efficiency (WUE) and the amount of irrigation applied for the manual and automatic control plots. management. A multi-nodal WSN was integrated with a center pivot system for monitoring crop water status and geo-positioning. Sustained data throughput throughout the growing season demonstrated an improved measure of network scalability and reliability compared to previous work with WSN systems and center pivots. The WSN and plant feedback system demonstrated successful automation in the control of irrigation scheduling and grain yield WUE of a short season sorghum in a severe drought season. Automatic irrigation scheduling based on wireless remote spatiotemporal monitoring of grain sorghum over the growing season resulted in dry grain yields and WUE that compared well to those from plots manually irrigated based on a soil water balance equation from direct soil water measurements using the neutron probe. The negative linear correlations between crop canopy temperature and irrigation levels, and grain yield and the average seasonal integrated CWSI demonstrated the utility of the wireless IRT nodes to identify spatiotemporal crop water stress. These results demonstrate the feasibility of using a WSN for large-scale agricultural production.

\section{ACKNOWLEDGEMENTS}

We gratefully acknowledge support from the USDAARS Ogallala Aquifer Program, a consortium between USDA-Agricultural Research Service, Kansas State University, Texas AgriLife Research, Texas AgriLife Extension Service, Texas Tech University, and West Texas A\&M University. Work reported in this paper was accomplished as part of a Cooperative Research and Development Agreement between USDA-ARS and Valmont Industries, Inc., Valley, Nebraska (Agreement No.: 58-3K95-0-1455-M). The authors also acknowledge the dedicated work performed by Luke Britten, Agricultural Science Technician, and Brice Ruthardt, Scientist, USDA-ARS, Conservation and Production Research Laboratory, Bushland, Texas.

\section{REFERENCES}

Balanis, C. A. 2005. Antenna Theory, Analysis and Design, 94-96. Hoboken, N.J.: John Wiley \& Sons, Inc.

Camilli, A., C. E. Cugnasca, A. M. Saraiva, A. R. Hirakawa, and P. L. P. Correa. 2007. From wireless sensors to field mapping: Anatomy of an application for precision agriculture. Comput. Electron. Agric. 58(1): 25-36.

Coates, P. W., and M. J. Delwiche. 2009. Site-specific water and chemical application by wireless valve controller network. ASABE Paper No. 084483. St. Joseph, Mich.: ASABE.

DeTar, W. R., and J. V. Penner. 2007. Airborne remote sensing used to estimate percent canopy cover and to extract canopy temperature from scene temperature in cotton. Trans. ASABE 50(2): 495-506.

Evett, S. R., T. A. Howell, A. D. Schneider, D. F. Wanjura, and D. R. Upchurch. 2002. Automatic drip irrigation control regulates water use efficiency. International Water and Irrig. 22(2): 32-37.

Evett, S. R. 2008. Neutron moisture meters. In Field Estimation of Soil Water Content: A Practical Guide to Methods, Instrumentation, and Sensor Technology, 39-54. S. R. Evett, L. K. Heng, P. Moutonnet, and M. L. Nguyen, eds. IAEA-TCS-30. Vienna, Austria: International Atomic Energy Agency. Available at http://www-pub.iaea.org/mtcd/publications/PubDetails.asp? pubId $=7801$. 
Gonzalez-Dugo, M. P., and L. Mateos. 2008. Spectral vegetation indices for benchmarking water productivity of irrigated cotton and sugar beet crops. Agric. Water Manage. 95(1):48-58.

Hunsaker, D. J., E. M. Barnes, T. R. Clarke, G. J. Fitzgerald, and P. J. Pinter Jr. 2005. Cotton irrigation scheduling using remotely sensed and FAO-56 basal crop coefficients. Trans ASAE 48(4): 1395-1407.

IEEE802.15.4f. 2011. Standard for Local and metropolitan area networks- Part 15.4: Low-rate Wireless Personal Area Networks (LR-WPANs). Amendment 2: Active Radio Frequency Identification (RFID) system Physical Layer (PHY). IEEE, Inc., 3 Park Avenue, New York, NY Available at: http://standards. ieee.org/about/get/802/802.15.html. Accessed 15 August 2013.

Jackson, R. D., S. B. Idso, R. J. Reginato, and P. J. Pinter. 1981. Canopy temperature as a crop water stress indicator. Water Resour. Res. 17(4): 1133-1138

Jackson, R. D., W. P. Kustas, and B. J. Choudhury. 1988. A reexamination of the crop water stress index. Irrig. Sci. 9(4): 309-317.

Kim, Y., and R. G. Evans. 2009. Software design for wireless sensor-based site-specific irrigation. Comput. Electron. Agric. 66(2): 159-165.

Kim, Y., R. G. Evans, and W. M. Iversen. 2009. Evaluation of closed-loop site-specific irrigation with wireless sensor network. J. Irrig. Drain. Eng. ASCE 135(1): 25-31.

Lamm, F. R., and R. M. Aiken. 2008. Comparison of temperaturetime and threshold-ET based irrigation scheduling for corn production. ASABE Paper No. 084202. St. Joseph, Mich.: ASABE.

Lee, W. S., V. Alchanatis, C. Yang, M. Hirafuji, D. Moshou, and C. Li. 2010. Sensing technologies for precision specialty crop production. Comput. Electron. Agric. 74(1): 2-33.

Li, Z., N. Wand, and T. Hong. 2010. Radio path-loss modeling for a $2.4 \mathrm{GHz}$ in-field wireless sensor network. Trans. ASABE 53(2): 615-624.

Littell, R. C., G. A. Milliken, W. W. Stroup, R. D. Wolfinger, and O. Schabenberger. 2006. SAS for Mixed Models. Second edition. Cary, N.C.: SAS Institute, Inc.

Lyle, W. M., and J. P. Bordovsky. 1983. LEPA irrigation system evaluation. Trans. ASAE 26(3): 776-781.

Matese, A., S. F. Di Gennaro, A. Zaldei, L. Genesio, and F. P. Vaccari. 2009. A wireless sensor network for precision viticulture: The NAV system. Comput. Electron. Agric. 69(1): 51-58.

Mirik, M., G. J. Michels Jr., S. Kassymzhanova-Mirik, and N. C. Elliott. 2007. Reflectance characteristics of Russian wheat aphid (Hemiptera: Aphididae) stress and abundance in winter wheat. Comput. Electron. Agric. 57(2): 123-134.

Moring, J. T. 2006. A survey of RF and wireless technology. In Handbook of RF and Wireless Technologies, 1-22. Burlington, Mass.: Newness Publications.

O'Shaughnessy, S. A., and S. R. Evett. 2010a. Canopy temperature based system effectively schedules and controls center pivot irrigation for cotton. Agric. Water Mgmt. 97(9): 1310-1316.
O'Shaughnessy, S. A., and S. R. Evett. 2010b. Developing wireless sensor networks for monitoring crop canopy temperature using a moving sprinkler system as a platform. Applied Eng. in Agric. 26(2): 331-341.

O'Shaughnessy, S. A., S. R. Evett, P. D. Colaizzi, and T. A. Howell. 2011a. Application Uniformity of a commercial center pivot variable rate irrigation system. Proc. Irrigation Show Technical Conference. San Diego, Calif.: Irrigation Association.

O’Shaughnessy, S.A., M. A. Hebel, S. R. Evett, and P. D. Colaizzi. 2011b. Evaluation of a wireless infrared thermometer with a narrow field of view. Comput. Electron. Agric. 76(1): 59-68.

O’Shaughnessy, S. A., S. R. Evett, P. D. Colaizzi, and T. A. Howell. $2011 \mathrm{c}$. Using radiation thermography and thermometry to evaluate crop water stress in soybean and cotton. Agric. Water Manage. 98(10): 1523-1535.

O'Shaughnessy, S. A., S. R. Evett, P. D. Colaizzi, and T. A. Howell. 2012a. Grain sorghum response to irrigation scheduling with the Time Temperature Threshold method and deficit irrigation. Trans. ASABE 55(2): 451-461.

O'Shaughnessy, S. A., S. R. Evett, P. D. Colaizzi, and T. A. Howell. $2012 \mathrm{~b}$. A crop water stress and time threshold for automatic irrigation scheduling of grain sorghum. Agric. Water Manage. 107: 122-132.

Peters, R. T., and S. R. Evett. 2004. Modeling diurnal canopy temperature dynamics using one-time-of-day measurements and a reference temperature curve. Agron. J. 96(6): 1553-1561.

Peters, R. T., and S. R. Evett. 2008. Automation of a center pivot using the temperature-time-threshold method of irrigation scheduling. J. Irrig. Drainage Engr. 134 (3): 286-290.

Rouse, J. W., R. H. Hass, J. A. Shell, and D. W. Deering. 1973. Monitoring vegetation systems in the Great Plains with ERTs-1. In Proceedings: of Third Earth Resources Technology Satellite Symposium, 309-317Godard Space Flight Center, Washington, D.C.: National Aeronautical and Space Administration.

Soil Survey Staff. 2004. National Soil Survey Characterization Data. Soil Survey Laboratory, National Soil Survey Center, USDA-NRCS - Lincoln, NE.

Tate, R. F., M. A. Hebel, and D. G. Watson. 2008. WSN link budget analysis for precision agriculture. ASABE Paper No. 084955. St. Joseph, Mich.: ASABE.

Viets, F. G. 1962. Fertilizers and the efficient use of water. $A d v$. Agron. 14: 223-264.

West, J. S., C. Bravo, R. Oberti, D. Lemaire, D. Moshou, and H. A. McCartney. 2003. The potential of optical canopy measurement for targeted control of field crop diseases. Annu. Rev. Phytophathol. 41593-614.

Yang, Z., M. N. Rao, N. C. Elliott, S. D. Kindler, and T. W. Popham. 2009. Differentiating stress induced by greenbugs and Russian wheat aphids in wheat using remote sensing. Comput. Electron. Agric. 67(1): 64-70. 